\title{
sciendo
}

\section{Evaluation of Product Competitiveness: A Case Study Analysis}

\author{
Nestor SHPAK ${ }^{1}$, Nadiya SELIUCHENKO', Viktoriya KHARCHUK, Nataliya KOSAR ${ }^{1}$, Włodzimierz \\ SROKA ${ }^{2}$
}

${ }^{1}$ Lviv Polytechnic National University, Bandery 12, Lviv, Ukraine

2WSB University, Faculty of Applied Sciences, Cieplaka 1c, 41-300 Dąbrowa Górnicza, Poland, wsroka@wsb.edu.pl (corresponding author)

Background and Purpose: The existing frameworks provide a superficial approach to the evaluation of product competitiveness which reveals the linkage between the level of product competitiveness and quantitative as well as qualitative factors that have the most significant impact thereon. Given this fact, the purpose of this paper is to elaborate a model for evaluating the competitiveness of sunflower packaged oil, considering both quantitative and qualitative factors that may alter it. Further, this model is being implemented to examine the most demanded Ukrainian sunflower oil brands in order to reveal possibilities for enhancing competitiveness.

Design/Methodology/Approach: The general methodology of the research includes elements of theoretical, empirical, qualitative and quantitative analyses. The theoretical analysis aims to shed light upon a different understanding of "the evaluation of competitiveness", as well as approaches and tools for analysing it. Empirical analysis focuses on observing official statistical data of the export of sunflower oil and future trends. Qualitative analysis consists in the identification, systematization and description of factors that affect the competitiveness of sunflower oil packaged. In turn, quantitative analysis is based on usage of the Fuzzy logic tool in order to evaluate the impact of complex and partial factors on the level of product competitiveness.

Results: This paper provides a business case for product competitiveness evaluation of a particular sunflower oil brand. Based on usage of the Fuzzy logic toolkit, the impact of complex and partial factors on competitiveness level was analysed. As a result, simulation of the competitiveness sensitivity of a particular oil brand on relevant complex factors that determine it competitiveness level was presented. This business case may help managers to channel their efforts and resources in the proper particular direction to increase product competitiveness and product positioning on the market.

Conclusion: The results of this research would be useful to practitioners in their assessment of product competitiveness, modelling future levels, and understanding hidden possibilities for enhancing product competitiveness. The framework offered might be adopted for other types of products.

Keywords: product competitiveness, general and partial factors, fuzzy logic.

\section{Introduction}

Nowadays, the highly competitive entrepreneurial environment - as well as market fluctuations - are noticeably observed in modern conditions of uncertainty, imbalance and disproportion between the expected and actual state of the market (Shpak et al., 2016). It demands business be focused on a number of aspects, e.g. CSR in its operations (Bhana, 2018; Sroka \& Vveinhardt, 2018; Kliestikova et al., 2018; Meyer, 2018), inter-organisational cooperation, both bilateral and multilateral (e.g. Kozma,

Received: March 9, 2019; revised: April 8, 2019; accepted: May 12, 2019 
2017, Šebestová et al., 2017), as well as coopetition, i.e. simultaneous cooperation and competition with competitors (Mohalajeng \& Kroon, 2016; Cygler \& Sroka, 2017; Cygler et al., 2018). The issue which is more and more important, especially in the developed countries, is also employment of older generation employees (Kolářová et al., 2017; Kubíčková et al., 2018). However, a matter of crucial importance for businesses is the production of a strongly competitive product. At the same time, product competitiveness is a broad phenomenon which is being considered from numerous points of view and related interdisciplinary areas. It is worth mentioning that different areas of business or industry branches create specific conditions and hence have a significant impact on product competitiveness. Considering such peculiarities, it is logical to focus research on a certain product.

One of the most important directions for economic development is to enhance product exporting and to promote national trademarks on international markets (Meyer \& Meyer, 2017; Meyer \& De Jongh, 2018). On the domestic market, each industry has in-demand and well-known products or trademarks. Nevertheless, Ukrainian companies are struggling on the global market. Such a situation is considered to be related to the level of product competitiveness for national trademarks in particular.

Observing the results of Ukrainian product exporting revealed that sunflower oil is one of the most in-demand products on the international market (SSSU, 2018). In particular, the share of Ukrainian oil production on the global market exceeds $50 \%$. However, sunflower oil contributed only one-third of the total Ukrainian exports (UCAB, 2018). The lack of this type of product in the export structure is caused by certain constraints.

In the face of increasing competition on the Ukrainian market, producers should pay considerable attention to improving the competitiveness of their products. From this perspective, the aim of the research is to investigate the relationship between the competitiveness of a particular product and numerous factors that affect the given product. Regarding all the above mentioned factors, assessing the competitiveness of sunflower oil allows researchers to compare different brands and to distinguish the most significant factors.

Our paper is structured as follows: Firstly, we present the theoretical background. Secondly, we present the methodology that was applied in this research. The next part of our paper presents the research results. Finally, we present the conclusions and limitations of our study.

\section{Theoretical background}

Product competitiveness discourse is the subject of heated debates by academics and practitioners (Oral \& Kettani, 2009; Roostika et al., 2015; Androniceanu, 2017; Popp et al., 2018a, 2018b). Nonetheless, there are some aspects that have been left untouched due to different purposes of investigation. The present paper proposes an overview of Ukrainian and international academics' scientific work pertaining to an evaluation of product competitiveness. The question of quantitative assessment of product competitiveness is always relevant for producers in order to determine strategy, namely to increase and / or expand their positions on both domestic and foreign markets.

An analysis of scientific publications reveals numerous models and frameworks for the evaluation of product competitiveness. The main approaches may be summarised as follows (Pastushchin, 2013: 232-240):

1) Methodology of the evaluation of product competitiveness through calculating its rating. According to this approach, product rating is dependent on product quality indicators (Kobilyatsky, 2003; Pomffyová et al., 2017; Dvorsky et al., 2018). Such a point of view brings some limitations because, in this case, managers neglect other product characteristics and internal and external environmental conditions (Androniceanu \& Popescu, 2017).

2) Methodology of the evaluation of product competitiveness through the volume of sales. This approach assumes that the volume of sales reflects consumer demand, which is why it might be the most significant criteria for its competitiveness. This approach focuses only on one product competitiveness characteristic which makes it rather narrow. Under modern conditions, a high volume of sales might be the result of a weak competitive environment and the absence of similar products on the market.

3) Methodology of the evaluation of product competitiveness through a complex index with multiple foci (Fatkhutdinov, 2000; Chepurnoy, 2005). According to this approach, a complex index of product competitiveness should include a set of partial indicators which generalise the following characteristics of product competitiveness: consumer requirements, technical requirements, enterprise expenses.

4) Methodology of the prediction index of competitive strength of alcohol brands based on Fuzzy logic (Shtovba, 2007). The authors offered a fuzzy model of brand competitiveness index which is based on expert knowledge bases (quality of the brand product, image of the brand product, and service connected with the brand product) and so on. 
On the basis of the given literature analysis, one can make a sweeping assumption that today there is an absence of an acknowledged approach that suits all aspects of the evaluation of product competitiveness. Scholars often use individual qualitative indicators which reflect different parameters of product competitiveness (e.g. Ivanenko, 2012; Stavenki \& Zhurilo, 2009), or group and integral indicators which generalise different characteristics of product competitiveness - consumer needs, competitor products that best meet consumer needs, the image of the enterprise, a hypothetical sample, and a group of analogue products (Litvinova, 2013; Massey et al., 2018).

It should be noted that models and frameworks for the evaluation of product competitiveness developed, first of all, separately for different industry branches. Such a variety of different approaches brought about specific peculiarities of each business area or market. Thus, it is hard to offer a unique model or framework that suits all peculiarities of the Ukrainian domestic market and might be adopted for different company/product characteristics.

In contrast, different holistic approaches for the evaluation of product competitiveness have been proposed in the literature. For example, Fumio (1985) introduced the scaling method based on rivalry comparison. He proposed the use of the maximum correlation ratio method for selecting the most significant characteristics of product competitiveness. In turn, Chang \& Yeh (2001) developed an approach to evaluating airline competitiveness based on the utilisation of the multiattribute decision-making model. This approach addressed the issue of identifying five dimensions of competitiveness and appropriate performance measures. To solve the problem of inconsistency during the validation procedure, the authors decided to use the additive weighting method, weighted product method and to allocate preferences according to similarity to the ideal result (providing the minimum expected loss of value). Such a combination of methods helps to reveal the competitive advantage of a particular company in comparison to its competitors. Oral \& Kettani (2009) proposed the industrial competitiveness model highlighting key points such as:

- adopting "scientific models" and "practical frameworks" in order to improve modelling of firm competitiveness for strategy formulation,

- developing a formal model - Integrated competitiveness model (ICM), which consists of four sub models and six indices,

developing sub-models and indices: actual output sub-model, comparative actual sub-model, potential sub-model, comparative potential sub-model, actual mastery index, actual cost superiority index, potential industrial mastery index, potential cost superiority index, actual competitiveness index, and potential competitiveness index,

- forming a competitive strategy according to links between companies' actual and potential competitiveness.
In general, one may conclude that many authors have highlighted the necessity of combining different methods in order to obtain a relevant evaluation of product competitiveness. Nevertheless, the models or frameworks considered, whether taken separately or in combination, do not comprehensively reflect the characteristics of product competitiveness. Along with complications in the Ukrainian economy, an evaluation of product competitiveness should be based not only on assessing set metrics that reflect peculiar characteristics, but should also include the internal and external environment of the particular companies.

\section{Methodology}

Existing dilemmas in the evaluation of product competitiveness provide the basis for a further contribution to solving this problem, in particular, developing a model for its assessment which might be applicable under changing environmental conditions. The conducted literature analysis has shown that the usage of economic-mathematical and expert methods, separately or in combination, for the evaluation of product competitiveness does not allow researchers to consider all product features (both quantitative and qualitative characteristics) and to eliminate the dependence of expert assessments on the subjective judgments of experts. So, it is logical to apply such a method that allows researchers to:

- simulate complex systems under conditions of insufficient information and randomness of processes,

- solve problems of aggregation of ambiguous, subjective and inaccurate expert judgments about the state of a particular parameter,

- reflect a complex nature of the evaluation of product competitiveness,

- consider numerous factors that affected product competitiveness.

As noted by a number of scholars (e.g. Pedrycz, 2011; Xianbo, et al., 2013; Marcos Duarte Jr., 2018; Moravcikova et al., 2017), the fuzzy logic toolkit provides an opportunity to obtain a fairly objective assessment as it takes into account all factors (both quantitative and qualitative), as well as the level of confidence of the experts who carry out the evaluation. Given this fact, this method was applied in our paper.

The methodology structure consists of two parts. The first stage was to choose the subject of research, in particular, the type of product for the evaluation of its competitiveness. For this purpose, the empirical analysis of packaged sunflower oil was conducted. In addition, factors that had the most significant impact on product competitiveness were identified and described. The second part was to construct a model for the evaluation of the competitiveness of sunflower oil by means of fuzzy logic tools. MATLAB software was used for modelling. 
The construction of the model using the Fuzzy Logic Toolbox package consisted of the following steps:

1. the definition of linguistic variables and their corresponding term sets,

2. the construction of the fuzzy set adjective, which includes: determining the range of changes in the data pertaining to competitiveness factors and the output variable - product competitiveness; choosing the type of fuzzy set adjective for each variable and justifying its parameters,

3. the formation of fuzzy knowledge bases,

4. assessing the adequacy of the model based on the training sample, adjusting its parameters and making a decision on the final version.

\section{Empirical analysis of sunflower oil exporting}

According to secondary financial data obtained from the State Statistics Service of Ukraine (SSSU, 2018), oil production and exports have been one of the most significant such items on the global market over the past few years. For instance, sales volumes of sunflower oil on international markets increased by $16 \%$ (597 million \$) in 2017 (Table 1).

In the course of the study, it was established that Ukraine has significant potential for increasing oil exports as it lacks restrictions on the export of various sunflower oil processing products to the foreign market. Meanwhile, the consumption of high quality, healthy food (including sunflower oil) has grown significantly. Taking into account the results of the study, packaged sunflower oil was selected for practical implementation of the process of evaluating product competitiveness.

Table 1: Input and output variables for the fuzzy inference system

\begin{tabular}{|c|l|l|l|l|l|c|c|}
\hline Year & Total & $\begin{array}{l}\text { CIS coun- } \\
\text { tries }\end{array}$ & EU & Asia & Africa & America & $\begin{array}{l}\text { Australia and } \\
\text { Oceania }\end{array}$ \\
\hline 2006 & 1628820,61 & 188594,15 & 861562,49 & 415846,54 & 162504,95 & 312,21 & 0,28 \\
\hline 2007 & 1923240,61 & 22947,81 & 982733,04 & 366905,45 & 342025,55 & 2098,28 & 0,17 \\
\hline 2008 & 1339557,44 & 205308,41 & 527647,63 & 398777,09 & 167907,69 & 39915,96 & 0,66 \\
\hline 2009 & 2333842,54 & 153718,89 & 629739,06 & 1052483,37 & 478161,11 & 19714,68 & 25,43 \\
\hline 2010 & 2688562,35 & 273224,57 & 716578,71 & 1175242,87 & 522797,75 & 587,92 & 130,53 \\
\hline 2011 & 2333842,54 & 153718,89 & 629739,06 & 1052483,37 & 478161,11 & 19714,68 & 25,43 \\
\hline 2012 & 3589606,45 & 112015,75 & 699046,84 & 2025268,68 & 736049,93 & 17221,23 & 3,99 \\
\hline 2013 & 3199506,79 & 108935,62 & 403363,34 & 2181825,95 & 479139,88 & 26134,50 & 107,49 \\
\hline 2014 & 4339490,34 & 87530,30 & 817372,41 & 2990921,31 & 433976,18 & 7039,77 & 2650,37 \\
\hline 2015 & 3938555,37 & 58851,57 & 744343,01 & 2818297,43 & 303438,00 & 12259,79 & 1365,57 \\
\hline 2016 & 4842064,81 & 44372,45 & 1396170,77 & 3071259,42 & 305086,75 & 21085,65 & 4089,70 \\
\hline 2017 & 5757344,05 & 35297,74 & 1812147,70 & 3615398,20 & 264153,71 & 24834,30 & 5512,39 \\
\hline
\end{tabular}

\subsection{Factors determining the competitiveness of packaged sunflower oil}

To ensure that all factors which influence product competitiveness were included in the evaluation process, an expert survey was conducted. The main aim of the survey was to identify a group of factors that determine product competitiveness. This survey reached 35 Ukrainian sunflower oil manufacturers, independently operated with different sizes and market shares, to obtain a relevant result. For the purposes of data collection, questionnaires were sent by e-mail to different groups of employees who have expertise connected with the company or product competitive- ness. In particular, the respondents were directors, CEOs, sales managers, marketers, and social media marketers.

Interviewees answered the following questions:

- which of the following factors affects the competitiveness of sunflower oil?

- what is the significance of each partial factor (significance was described verbally: important and irrelevant)?

- what is the nature of the relationship between each factor and the level of competitiveness: direct or inverse?

- what are possible combinations of factors based on their levels (levels were described verbally: 
low, medium, high) ?

- what is the range of change in quantitative factors (the range was determined based on the secondury data analysis)?

Questionnaires included the title and description of numerous factors with possible combination of all complex and partial factors. It is worth mentioning that during preparation of the survey questionnaires (and complex factors identification in particular), existing Ukrainian frameworks on a given issue were used (Shtovba, 2007; Shtovba \& Shtovba, 2005) and secondary data analysis. Therefore, among these factors, only price might be presented in quantitative terms. Quality, image, and service belong to qualitative factors. In addition, they are complex (aggregated), since each of them depends on a number of partial factors.

After collecting all filled-in questionnaires, the researchers revised the interviewer's responses.

As a result of the analysis of the questionnaires, we identified complex and partial factors that influence the level of competitiveness of sunflower oil.
On the basis of the survey results, partial factors, both quantitative and qualitative ones, were established. Table 2 illustrates the final list of the complex and partial factors of the competitiveness of packaged sunflower oil, together with their description.

\subsection{Definition of linguistic variables and their corresponding term sets}

Quality, image and service are complex factors and each of them depends on a number of partial factors. Considering the important for decision making to have assessments of complex factors, we decided to build a separate fuzzy knowledge base for each complex factor and fuzzy knowledge base for assessing the level of competitiveness. In addition, Shtovba (2005) and Miller (1956) argue that in the case of a large number of expert input it is difficult to describe causal relationships with fuzzy rules. Therefore, they recommend building fuzzy knowledge bases that have no more than 5-7 input parameters. As a result, the

Table 2: Factors that affect the level of competitiveness of packaged sunflower oil. Source: own

\begin{tabular}{|c|c|c|}
\hline Complex factors & Partial factors & Factors characteristics \\
\hline \multirow[t]{5}{*}{ Quality $\left(\mathrm{F}_{1}\right)$} & $\begin{array}{l}\text { Genetic seed purity } \\
\left(\mathrm{F}_{11}\right)\end{array}$ & $\begin{array}{l}\text { Sunflower seeds characterise genetic and physiological information, } \\
\text { primarily about the ratio of spare and biologically active substances. The } \\
\text { genetic purity of the seeds is determined not only by its genetic compo- } \\
\text { nent but also by the conditions of cultivation and cultivation (cleansing, } \\
\text { calibration, protrusion, and packing) of seeds. }\end{array}$ \\
\hline & Primary product quality $\left(\mathrm{F}_{12}\right)$ & $\begin{array}{l}\text { It depends not only on the seeds but also on the conditions of growing } \\
\text { sunflowers, the time of harvesting, transportation, further storage, and } \\
\text { processing. } \\
\text { All products must comply with the regulatory requirements of the } \\
\text { National Standards of Ukraine } 4694-2006 \text {. Depending on the criteria for } \\
\text { the quality of sunflower seeds, it may be categorised as higher, first or } \\
\text { second class. Olive factories buy sunflower, the humidity of which varies } \\
\text { from } 6 \% \text { to } 8 \% \text {, with a content of garbage impurity - } 3 \% \text {, which is not } \\
\text { infected with pests, except infection of the second mite. The sunflower } \\
\text { seeds must not be bitter, are discarded by colour and odour, and the } \\
\text { maximum allowable dose of residual quantities of pesticides, chemicals, } \\
\text { and heavy metals is determined. }\end{array}$ \\
\hline & $\begin{array}{l}\text { Innovation of production and } \\
\text { logistics technologies }\left(\mathrm{F}_{13}\right)\end{array}$ & $\begin{array}{l}\text { Production assets renovation funds the usage of new recipes, modern } \\
\text { storage methods and means for transportation of oils }\end{array}$ \\
\hline & Staff quality $\left(\mathrm{F}_{14}\right)$ & Qualification, staff motivation, discipline in the production process \\
\hline & $\begin{array}{l}\text { Degree of burnout during } \\
\text { usage }\left(\mathrm{F}_{15}\right)\end{array}$ & $\begin{array}{l}\text { Determined by how much oil is needed, especially when cooking prod- } \\
\text { ucts that require frying }\end{array}$ \\
\hline
\end{tabular}


Table 2: Factors that affect the level of competitiveness of packaged sunflower oil. (continued)

\begin{tabular}{|c|c|c|}
\hline \multirow[t]{6}{*}{ Image $\left(\mathrm{F}_{2}\right)$} & $\begin{array}{l}\text { Implementation of socially re- } \\
\text { sponsible projects tend towards } \\
\text { external company environment } \\
\left(\mathrm{F}_{21}\right)\end{array}$ & $\begin{array}{l}\text { Participation in charity events; } \\
\text { Level of care for packaging recycling }\end{array}$ \\
\hline & \begin{tabular}{|l|} 
Implementation of socially re- \\
sponsible projects tend towards \\
internal company environment \\
$\left(\mathrm{F}_{22}\right)$ \\
\end{tabular} & Taking care of staff, their development, and general working conditions \\
\hline & $\begin{array}{l}\text { The level of distribution of } \\
\text { negative reviews about a par- } \\
\text { ticular trademark }\left(\mathrm{F}_{23}\right)\end{array}$ & $\begin{array}{l}\text { Spreading negative information about the company and its products on } \\
\text { the Internet and at retail intermediaries }\end{array}$ \\
\hline & $\begin{array}{l}\text { The level of green technologies } \\
\text { used in production }\left(\mathrm{F}_{24}\right)\end{array}$ & $\begin{array}{l}\text { The technological process must be safe for the environment and antici- } \\
\text { pate the use of alternative energy sources }\end{array}$ \\
\hline & $\begin{array}{l}\text { Foreign investment share in } \\
\text { registered capital }\left(\mathrm{F}_{25}\right)\end{array}$ & $\begin{array}{l}\text { Allows firms to invest more in socially responsible activities, green } \\
\text { technologies, and improve sales and logistics }\end{array}$ \\
\hline & $\begin{array}{l}\text { Number of international quali- } \\
\text { ty certificates }\left(\mathrm{F}_{26}\right)\end{array}$ & $\begin{array}{l}\text { Certificate of Quality Management System, Certificates of Compli- } \\
\text { ance with International Requirements Kosher P1 and P2, Certificate of } \\
\text { production according to European organic requirements, Certificates for } \\
\text { the food safety system, namely ISO 22000:2005, ISO/TS 22002-1:2009 } \\
\text { and additional requirements FSSC 22000, availability of Eco standard. } \\
\text { Management systems should be certified in accordance with internation- } \\
\text { al standards such as ISO } 9001 \text { (quality) and ISO } 14001 \text { (environmental } \\
\text { protection) }\end{array}$ \\
\hline \multirow[t]{3}{*}{ Service $\left(\mathrm{F}_{3}\right)$} & $\begin{array}{l}\text { Product availability in retail } \\
\text { trade }\left(\mathrm{F}_{31}\right)\end{array}$ & $\begin{array}{l}\text { The number of retail intermediaries involved in product sales; distribu- } \\
\text { tion geography }\end{array}$ \\
\hline & $\begin{array}{l}\text { Frequency of shares held by } \\
\text { the producer together with the } \\
\text { trade intermediaries for the } \\
\text { final consumer (per year) }\left(\mathrm{F}_{32}\right) \\
\end{array}$ & $\begin{array}{l}\text { Carrying out actions to stimulate sales - providing discounts on products; } \\
\text { drawings among consumers for the best dish recipes }\end{array}$ \\
\hline & $\begin{array}{l}\text { Information support to inter- } \\
\text { mediaries and final consumers } \\
\left(\mathrm{F}_{33}\right)\end{array}$ & $\begin{array}{l}\text { Providing intermediaries with information about their products, their } \\
\text { quality parameters and outdoor advertising media; advertising in mass } \\
\text { media, and on the Internet, presence in social networks with the offer of } \\
\text { original recipes; information content of the site; informing intermediar- } \\
\text { ies and producers about sales promotion incentives, producer participa- } \\
\text { tion in exhibitions and fairs }\end{array}$ \\
\hline Price $\left(\mathrm{F}_{4}\right)$ & Retail price & $\begin{array}{l}\text { Determined by the cost of oil production, the profitability of production } \\
\text { and trade margins of intermediaries, as well as consumer demand }\end{array}$ \\
\hline
\end{tabular}


fuzzy model for assessing the competitiveness of oil will include four expert knowledge bases.

Firstly, complex factors are evaluated on the basis of partial factors, and then, based on the obtained estimates of complex factors, the level of competitiveness oil was estimated (the fuzzy values of the estimates of complex factors are defuzzificationed and their crisp values are already given to the fuzzy system of the next level). The output tree of the evaluation of the competitiveness of oil is presented in Figure 1.

Linguistic variables were defined on the basis of the output tree. Hence, the hierarchical model includes the following linguistic variables: at the 1 st level -14; at the 2nd level -4 ; on the 3 rd level -1 . We assigned the titles corresponding to the names of the highlighted competitiveness factors to the linguistic variables of the 1 st and 2 nd level. The output linguistic variable will be called "Oil Competitiveness Level". All linguistic variables may have three meanings: low; medium; high.

For each variable in the model, three terms were select- ed. This is due to the fact that a greater number of fuzzy terms with a large number of input variables would complicate the process of knowledge base formation.

In the future, the term set of all linguistic variables will be denoted accordingly $\{\mathrm{L}, \mathrm{M}, \mathrm{H}\}$.

\subsubsection{Construction of membership functions of fuzzy terms}

In order to describe the linguistic terms "low", "medium" and "high", it is necessary to build membership functions. The construction of membership functions of fuzzy terms involves solving problems including (Shtovba, 2007; Matviychyk, 2005):

- determining the range of changes in the values of the input variables (competitiveness factors) and the output variable (the competitiveness of sunflower oil),

- $\quad$ selection of membership function type for each variable and the justification of its parameters.

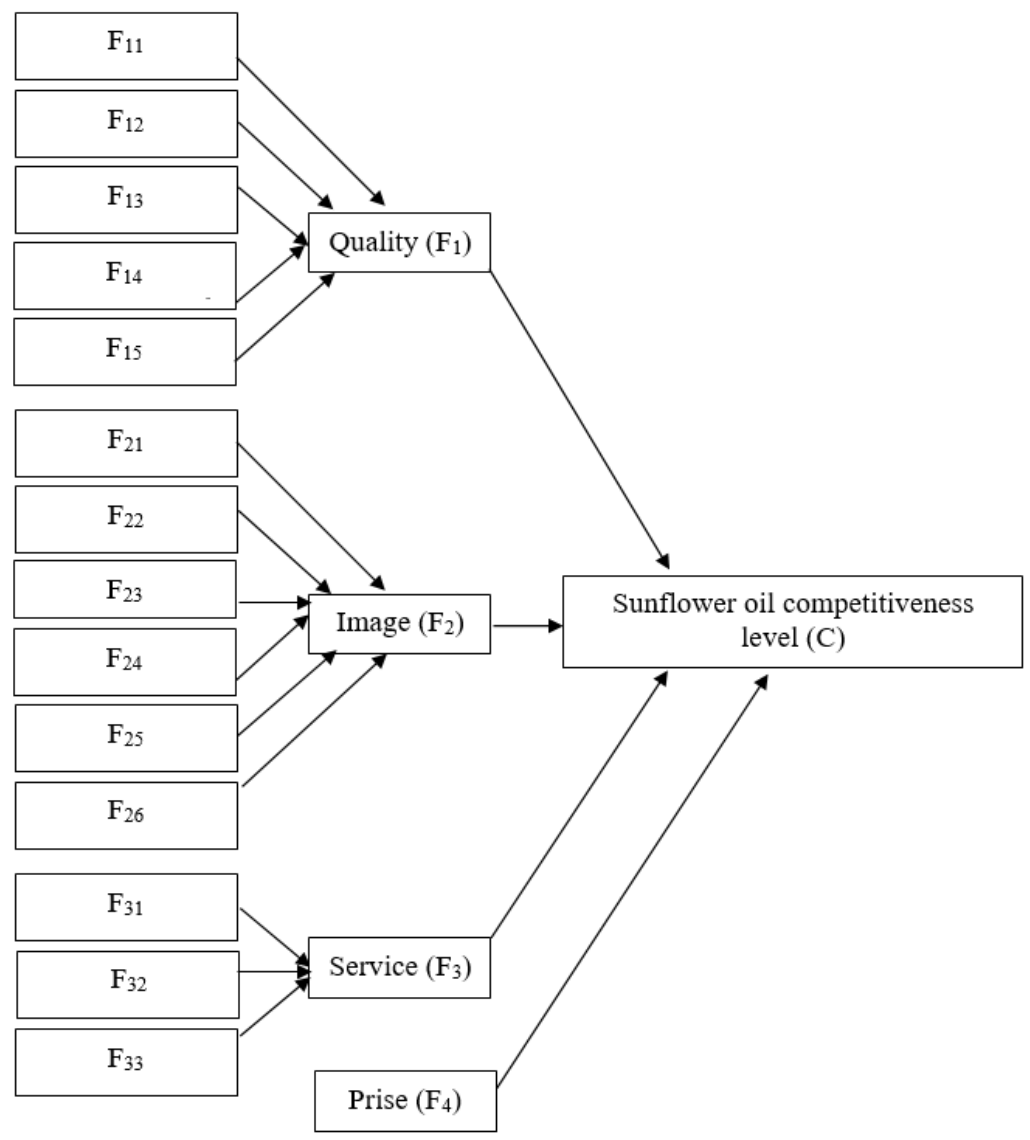

Figure 1: Graphic visualization of the relationship between factors of the competitiveness of sunflower oil. Source: own 
The criterion pertaining to the level of competitiveness of oil is to choose the real number $\mathrm{C}$, which belongs to the interval $[0 ; 100]$. In terms of an assessment of the qualitative factors of competitiveness (partial and complex), it is also advisable to choose actual numbers from the range $[0 ; 100]$.

Among the highlighted competitiveness factors are the following quantitative ones, in particular: the share of foreign investment in the registered capital (F25), the number of international quality certificates (F26), the frequency of shares held by the manufacturer together with the intermediary for the final consumer (F32), and price (F4). Evidently, the share of foreign investment in registered capital (expressed as a percentage) may vary within $[0 ; 100]$. The range of changes in other factors we determined on the basis of a survey of experts: F26 $€[0 ; 10]$; F32 $€[0 ; 12]$; F4 $€[25 ; 40]$.

The higher the value of the number, the higher the oil competitiveness level or the factor affecting it. However, it is necessary to take into account that the relationship between factors and the level of competitiveness can be either direct or inverse. Most of the factors have a direct impact on oil competitiveness. Factors reducing the level of competitiveness include the following: the level of burnout during usage (F15), the level of negative feedback about the particular trademark (F23), and price (F4).

The fuzzy logic toolkit in the MATLAB package contains built-in membership functions. To assess the competitiveness of the oil, we used a number of qualitative vari- ables that can only be evaluated by an expert. Therefore, we could not form a classic statistical sample. We have selected a symmetric Gauss curve. The advantage of this function is that only two parameters need to be specified for its construction, and it is sufficiently flexible.

In the Fuzzy Logic Toolbox, Gaussian membership functions are given as follows: (x, params), where $\mathrm{x}$ is the vector for which the membership levels are calculated; params is a vector of the membership function parameters that are set in such order [c b], where $\mathrm{c}$ is the curve's span, and $b$ is the coordinate of the maximum of the membership function. The parameters of the membership functions are set automatically in such a way as to evenly cover the range of values of the linguistic variable. Taking into account the nature of the linguistic variables of our model, we leave the given parameters unchanged (Table 3).

\subsubsection{Formation of fuzzy knowledge bases}

In order to simulate the complex factors (quality, image, service) and the competitiveness of oil, fuzzy knowledge bases of the Mamdani type were formed (Mamdani \& Assilian, 1975) (Tables 4-7).

All the rules contain only logical "And" operations and have weights equal to one.

Fuzzy rules were built as a result of expert's survey. Possible combinations of partial and complex factors regarding their levels were specified, as a result of expert's survey.

In Table 7, we took into account the risk of oil quality de-

Table 3: Membership function parameters for the evaluation of oil competitiveness. Source: own

\begin{tabular}{|c|c|}
\hline Linguistic variables & Membership functions parameters \\
\hline $\begin{array}{l}\text { Genetic seed purity } \\
\text { Primary product quality } \\
\text { Innovation of production and logistics technologies } \\
\text { Staff quality } \\
\text { Degree of burnout during usage }\end{array}$ & $\begin{array}{l}\text { Range of all variables values change }[0 ; 100] \\
\text { Params: } \\
\text { «Low»: }[21.23 ;-4.441 \mathrm{e}-16] \\
\text { «Medium»: }[21.23 ; 50] \\
\text { «High»: }[21.23 ; 100]\end{array}$ \\
\hline $\begin{array}{l}\text { Image } \\
\text { Implementation of socially responsible projects tend towards } \\
\text { external company environment } \\
\text { Implementation of socially responsible projects tend towards } \\
\text { internal company environment } \\
\text { The level of distribution of negative reviews about a particu- } \\
\text { lar trademark } \\
\text { The level of green technologies used in production } \\
\text { Foreign investment share in registered capital } \\
\text { Number of international quality certificates }\end{array}$ & $\begin{array}{l}\text { Range of all variables values change }[0 ; 100] \\
\text { Params: } \\
\text { «Low»: }[21.23 ;-4.441 \mathrm{e}-16] \\
\text { «Medium»: }[21.23 ; 50] \\
\text { «High»: }[21.23 ; 100] \\
\text { Variable value change range }[0 ; 10] \\
\text { Params: } \\
\text { «Low»: }[1.699 ; 6.939 \mathrm{e}-17] \\
\text { «Medium»: }[1.699 ; 5] \\
\text { «High»: }[1.699 ; 9.974]\end{array}$ \\
\hline
\end{tabular}




\begin{tabular}{|c|c|}
\hline $\begin{array}{l}\text { Service } \\
\text { Product availability in retail trade, Information support to } \\
\text { intermediaries and final consumers } \\
\text { Frequency of shares held by the producer together with the } \\
\text { trade intermediaries for the final consumer (per year) }\end{array}$ & $\begin{array}{l}\text { Range of all variables values change }[0 ; 100] \\
\text { Params: } \\
\text { «Low»: }[21.23 ;-4.441 \mathrm{e}-16] \\
\text { «Medium»: }[21.23 ; 50] \\
\text { «High»: }[21.23 ; 100] \\
\text { Variable value change range }[0 ; 12] \\
\text { Params: } \\
\text { «Low»: }[2.548 ; 1.11 \mathrm{e}-16] \\
\text { «Medium»: }[2.548 ; 6] \\
\text { «High»: }[2.548 ; 12]\end{array}$ \\
\hline Price & $\begin{array}{l}\text { Variable value change range }[25 ; 40] \\
\text { Params: } \\
\text { «Low»: }[3.185 ; 25] \\
\text { «Medium»: }[3.185 ; 32.5] \\
\text { «High»: }[3.185 ; 40]\end{array}$ \\
\hline Oil competitiveness level & $\begin{array}{l}\text { Variable value change range }[0 ; 100] \\
\text { Params: } \\
\text { «Low»: }[21.23 ;-4.441 \mathrm{e}-16] \\
\text { «Medium»: }[21.23 ; 50] \\
\text { «High»: }[21.23 ; 100]\end{array}$ \\
\hline
\end{tabular}

The graph of fuzzy terms membership functions to the linguistic variable "Oil competitiveness level" is shown in Figure 2.

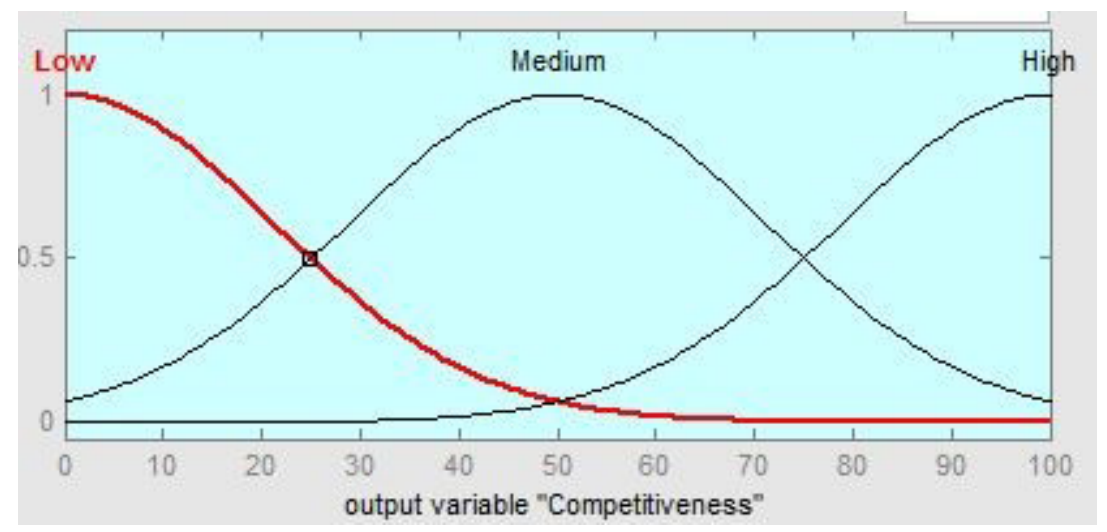

Figure 2: Fuzzy terms membership functions for the prediction of oil competitiveness level. Source: own 
creasing, even when the manufacturer has a high image and provides a high level of service (although experts argue that such manufacturers carry out strict quality con- trol, and the likelihood of non-identification of oil quality mismatches to established national standards is very low).

\section{Table 4: Fuzzy knowledge base for the evaluation of oil quality. Source: own}

\begin{tabular}{|c|c|c|c|c|c|c|}
\hline \multirow[t]{2}{*}{ No. } & \multicolumn{5}{|c|}{ If } & \multirow{2}{*}{$\begin{array}{c}\text { Then } \\
\text { Quality }\left(\mathrm{F}_{1}\right) \\
\end{array}$} \\
\hline & $\mathrm{F}_{11}$ & $\mathrm{~F}_{12}$ & $\mathrm{~F}_{13}$ & $\mathrm{~F}_{14}$ & $\mathrm{~F}_{15}$ & \\
\hline 1 & $\mathrm{H}$ & $\mathrm{H}$ & $\mathrm{H}$ & $\mathrm{H}$ & $\mathrm{L}$ & $\mathrm{H}$ \\
\hline 2 & $\mathrm{H}$ & $\mathrm{H}$ & $\mathrm{H}$ & $\mathrm{M}$ & $\mathrm{L}$ & $\mathrm{H}$ \\
\hline 3 & $\mathrm{H}$ & $\mathrm{H}$ & $\mathrm{M}$ & $\mathrm{H}$ & $\mathrm{L}$ & $\mathrm{M}$ \\
\hline 4 & $\mathrm{H}$ & $\mathrm{M}$ & $\mathrm{H}$ & $\mathrm{H}$ & $\mathrm{L}$ & M \\
\hline 5 & $\mathrm{M}$ & $\mathrm{H}$ & $\mathrm{H}$ & $\mathrm{H}$ & $\mathrm{L}$ & $\mathrm{M}$ \\
\hline 6 & $\mathrm{H}$ & $\mathrm{H}$ & $\mathrm{H}$ & $\mathrm{H}$ & $\mathrm{M}$ & $\mathrm{M}$ \\
\hline 7 & $\mathrm{H}$ & $\mathrm{H}$ & $\mathrm{H}$ & $\mathrm{M}$ & $\mathrm{M}$ & $\mathrm{M}$ \\
\hline 8 & $\mathrm{H}$ & $\mathrm{H}$ & $\mathrm{M}$ & $\mathrm{M}$ & $\mathrm{M}$ & $\mathrm{M}$ \\
\hline 9 & $\mathrm{H}$ & $\mathrm{M}$ & $\mathrm{M}$ & $\mathrm{M}$ & $\mathrm{M}$ & $M$ \\
\hline 10 & $\mathrm{H}$ & $\mathrm{M}$ & $\mathrm{M}$ & $\mathrm{M}$ & $\mathrm{M}$ & $M$ \\
\hline 11 & $\mathrm{M}$ & $\mathrm{M}$ & $\mathrm{M}$ & $\mathrm{M}$ & $\mathrm{M}$ & $\mathrm{M}$ \\
\hline 12 & $\mathrm{M}$ & $\mathrm{M}$ & $\mathrm{M}$ & $\mathrm{H}$ & $\mathrm{M}$ & $\mathrm{M}$ \\
\hline 13 & $\mathrm{M}$ & $\mathrm{M}$ & $\mathrm{H}$ & $\mathrm{M}$ & $\mathrm{M}$ & $\mathrm{M}$ \\
\hline 14 & $\mathrm{M}$ & $\mathrm{H}$ & $\mathrm{M}$ & $\mathrm{M}$ & $\mathrm{M}$ & $\mathrm{M}$ \\
\hline 15 & $\mathrm{M}$ & $\mathrm{M}$ & $\mathrm{M}$ & $\mathrm{L}$ & $\mathrm{M}$ & $\mathrm{M}$ \\
\hline 16 & $\mathrm{M}$ & $\mathrm{M}$ & $\mathrm{M}$ & $\mathrm{M}$ & $\mathrm{H}$ & $\mathrm{L}$ \\
\hline 17 & $\mathrm{M}$ & $\mathrm{M}$ & $\mathrm{L}$ & $\mathrm{M}$ & $\mathrm{M}$ & $\mathrm{L}$ \\
\hline 18 & $\mathrm{M}$ & $\mathrm{L}$ & $\mathrm{M}$ & $\mathrm{M}$ & $\mathrm{M}$ & $\mathrm{L}$ \\
\hline 19 & $\mathrm{~L}$ & $\mathrm{M}$ & $\mathrm{M}$ & $\mathrm{M}$ & $\mathrm{M}$ & $\mathrm{L}$ \\
\hline 20 & $\mathrm{~L}$ & $\mathrm{~L}$ & $\mathrm{M}$ & $\mathrm{M}$ & $\mathrm{M}$ & $\mathrm{L}$ \\
\hline 21 & $\mathrm{~L}$ & $\mathrm{~L}$ & $\mathrm{~L}$ & $\mathrm{M}$ & $\mathrm{M}$ & $\mathrm{L}$ \\
\hline 22 & $\mathrm{~L}$ & $\mathrm{~L}$ & $\mathrm{~L}$ & $\mathrm{~L}$ & $\mathrm{M}$ & $\mathrm{L}$ \\
\hline 23 & $\mathrm{~L}$ & $\mathrm{~L}$ & $\mathrm{~L}$ & $\mathrm{~L}$ & $\mathrm{~L}$ & $\mathrm{~L}$ \\
\hline
\end{tabular}

Table 5: Fuzzy knowledge base for image evaluation. Source: own

\begin{tabular}{|c|c|c|c|c|c|c|c|}
\hline \multirow[t]{2}{*}{ No. } & \multicolumn{5}{|c|}{ If } & \multirow[b]{2}{*}{$\mathrm{F}_{26}$} & \multirow{2}{*}{$\begin{array}{c}\text { Then } \\
\text { Quality }\left(\mathrm{F}_{2}\right)\end{array}$} \\
\hline & $\mathrm{F}_{21}$ & $\mathrm{~F}_{22}$ & $\mathrm{~F}_{23}$ & $\mathrm{~F}_{24}$ & $\mathrm{~F}_{25}$ & & \\
\hline 1 & $\mathrm{H}$ & $\mathrm{H}$ & $\mathrm{L}$ & $\mathrm{H}$ & $\mathrm{H}$ & $\mathrm{H}$ & $\mathrm{H}$ \\
\hline 2 & $\mathrm{H}$ & $\mathrm{H}$ & $\mathrm{L}$ & $\mathrm{H}$ & $\mathrm{H}$ & $\mathrm{M}$ & $\mathrm{H}$ \\
\hline 3 & $\mathrm{H}$ & $\mathrm{H}$ & $\mathrm{L}$ & $\mathrm{H}$ & $\mathrm{M}$ & $\mathrm{H}$ & $\mathrm{H}$ \\
\hline 4 & $\mathrm{H}$ & $\mathrm{M}$ & $\mathrm{L}$ & $\mathrm{H}$ & $\mathrm{H}$ & $\mathrm{H}$ & $\mathrm{H}$ \\
\hline 5 & $\mathrm{M}$ & $\mathrm{H}$ & $\mathrm{L}$ & $\mathrm{H}$ & $\mathrm{H}$ & $\mathrm{H}$ & $M$ \\
\hline 6 & $\mathrm{M}$ & $\mathrm{M}$ & $\mathrm{L}$ & $\mathrm{H}$ & $\mathrm{H}$ & $\mathrm{H}$ & $\mathrm{M}$ \\
\hline 7 & $\mathrm{M}$ & $\mathrm{M}$ & $\mathrm{M}$ & $\mathrm{M}$ & $\mathrm{H}$ & $\mathrm{M}$ & $\mathrm{M}$ \\
\hline 8 & $\mathrm{M}$ & $\mathrm{M}$ & $\mathrm{M}$ & $\mathrm{M}$ & $\mathrm{M}$ & $\mathrm{M}$ & $\mathrm{M}$ \\
\hline 9 & $\mathrm{M}$ & $\mathrm{M}$ & $\mathrm{H}$ & $\mathrm{M}$ & $\mathrm{M}$ & $\mathrm{M}$ & $\mathrm{L}$ \\
\hline
\end{tabular}


Table 5: Fuzzy knowledge base for image evaluation. (continued)

\begin{tabular}{|l|c|c|c|c|c|c|c|}
\hline 10 & $\mathrm{M}$ & $\mathrm{M}$ & $\mathrm{H}$ & $\mathrm{L}$ & $\mathrm{M}$ & $\mathrm{M}$ & $\mathrm{L}$ \\
\hline 11 & $\mathrm{M}$ & $\mathrm{L}$ & $\mathrm{H}$ & $\mathrm{L}$ & $\mathrm{M}$ & $\mathrm{M}$ & $\mathrm{L}$ \\
\hline 12 & $\mathrm{~L}$ & $\mathrm{M}$ & $\mathrm{H}$ & $\mathrm{L}$ & $\mathrm{M}$ & $\mathrm{M}$ & $\mathrm{L}$ \\
\hline 13 & $\mathrm{M}$ & $\mathrm{M}$ & $\mathrm{H}$ & $\mathrm{L}$ & $\mathrm{L}$ & $\mathrm{M}$ & $\mathrm{L}$ \\
\hline 14 & $\mathrm{M}$ & $\mathrm{M}$ & $\mathrm{H}$ & $\mathrm{L}$ & $\mathrm{L}$ & $\mathrm{L}$ & $\mathrm{L}$ \\
\hline
\end{tabular}

Table 6: Fuzzy knowledge base for service evaluation. Source: own

\begin{tabular}{|c|c|c|c|c|}
\hline \multirow{2}{*}{ No. } & \multicolumn{3}{|c|}{ If } & Then \\
\cline { 2 - 5 } & $\mathrm{F}_{31}$ & $\mathrm{~F}_{32}$ & $\mathrm{~F}_{33}$ & Quality $\left(\mathrm{F}_{3}\right)$ \\
\hline 1 & $\mathrm{H}$ & $\mathrm{H}$ & $\mathrm{H}$ & $\mathrm{H}$ \\
\hline 2 & $\mathrm{H}$ & $\mathrm{M}$ & $\mathrm{H}$ & $\mathrm{H}$ \\
\hline 3 & $\mathrm{M}$ & $\mathrm{H}$ & $\mathrm{H}$ & $\mathrm{M}$ \\
\hline 4 & $\mathrm{H}$ & $\mathrm{H}$ & $\mathrm{M}$ & $\mathrm{M}$ \\
\hline 5 & $\mathrm{M}$ & $\mathrm{H}$ & $\mathrm{H}$ & $\mathrm{M}$ \\
\hline 6 & $\mathrm{M}$ & $\mathrm{M}$ & $\mathrm{M}$ & $\mathrm{M}$ \\
\hline 7 & $\mathrm{H}$ & $\mathrm{M}$ & $\mathrm{M}$ & $\mathrm{M}$ \\
\hline 8 & $\mathrm{M}$ & $\mathrm{L}$ & $\mathrm{H}$ & $\mathrm{M}$ \\
\hline 9 & $\mathrm{H}$ & $\mathrm{L}$ & $\mathrm{M}$ & $\mathrm{M}$ \\
\hline 10 & $\mathrm{H}$ & $\mathrm{L}$ & $\mathrm{M}$ & $\mathrm{M}$ \\
\hline 11 & $\mathrm{M}$ & $\mathrm{M}$ & $\mathrm{M}$ & $\mathrm{M}$ \\
\hline 12 & $\mathrm{~L}$ & $\mathrm{~L}$ & $\mathrm{~L}$ & $\mathrm{~L}$ \\
\hline 13 & $\mathrm{~L}$ & & $\mathrm{~L}$ \\
\hline
\end{tabular}

Table 7: Fuzzy knowledge base for the evaluation of sunflower oil competitiveness. Source: own

\begin{tabular}{|c|c|c|c|c|c|}
\hline \multirow[t]{2}{*}{ No. } & \multicolumn{4}{|c|}{ If } & \multirow{2}{*}{$\begin{array}{c}\text { Then } \\
\begin{array}{c}\text { Sunflower oil competitive- } \\
\text { ness level }(C)\end{array}\end{array}$} \\
\hline & Quality $\left(\mathrm{F}_{1}\right)$ & $\operatorname{Image}\left(F_{2}\right)$ & Service $\left(F_{3}\right)$ & Price $\left(F_{4}\right)$ & \\
\hline 1 & $\mathrm{H}$ & $\mathrm{H}$ & $\mathrm{H}$ & $\mathrm{L}$ & $\mathrm{H}$ \\
\hline 2 & $\mathrm{H}$ & $\mathrm{H}$ & $\mathrm{H}$ & $\mathrm{M}$ & $\mathrm{H}$ \\
\hline 3 & $\mathrm{H}$ & $\mathrm{H}$ & M & $\mathrm{L}$ & $\mathrm{H}$ \\
\hline 4 & $\mathrm{H}$ & $\mathrm{H}$ & $\mathrm{M}$ & M & $\mathrm{H}$ \\
\hline 5 & $\mathrm{H}$ & M & $\mathrm{H}$ & $\mathrm{L}$ & $\mathrm{H}$ \\
\hline 6 & $\mathrm{H}$ & M & M & $\mathrm{L}$ & $\mathrm{H}$ \\
\hline 7 & $\mathrm{H}$ & $\mathrm{H}$ & $\mathrm{H}$ & $\mathrm{H}$ & M \\
\hline 8 & $\mathrm{H}$ & $\mathrm{H}$ & M & $\mathrm{H}$ & M \\
\hline 9 & $\mathrm{H}$ & $\mathrm{M}$ & $\mathrm{H}$ & $\mathrm{M}$ & $\mathrm{M}$ \\
\hline 10 & $\mathrm{H}$ & M & M & M & $\mathrm{M}$ \\
\hline 11 & M & M & M & M & M \\
\hline 12 & $\mathrm{M}$ & $\mathrm{M}$ & $\mathrm{M}$ & $\mathrm{L}$ & $\mathrm{M}$ \\
\hline 13 & M & $\mathrm{M}$ & $\mathrm{L}$ & $\mathrm{L}$ & M \\
\hline 14 & $\mathrm{M}$ & $\mathrm{H}$ & $\mathrm{H}$ & $\mathrm{H}$ & $\mathrm{M}$ \\
\hline
\end{tabular}


Table 7: Fuzzy knowledge base for the evaluation of sunflower oil competitiveness. (continued)

\begin{tabular}{|c|c|c|c|c|c|}
\hline 15 & $\mathrm{H}$ & $\mathrm{M}$ & $\mathrm{H}$ & $\mathrm{H}$ & $\mathrm{M}$ \\
\hline 16 & $\mathrm{M}$ & $\mathrm{H}$ & $\mathrm{M}$ & $\mathrm{H}$ & $\mathrm{M}$ \\
\hline 17 & $\mathrm{M}$ & $\mathrm{M}$ & $\mathrm{M}$ & $\mathrm{H}$ & $\mathrm{L}$ \\
\hline 18 & $\mathrm{M}$ & $\mathrm{M}$ & $\mathrm{L}$ & $\mathrm{M}$ & $\mathrm{L}$ \\
\hline 19 & $\mathrm{M}$ & $\mathrm{M}$ & $\mathrm{L}$ & $\mathrm{H}$ & $\mathrm{L}$ \\
\hline 20 & $\mathrm{M}$ & $\mathrm{L}$ & $\mathrm{M}$ & $\mathrm{M}$ & $\mathrm{L}$ \\
\hline 21 & $\mathrm{M}$ & $\mathrm{L}$ & $\mathrm{L}$ & $\mathrm{M}$ & $\mathrm{L}$ \\
\hline 22 & $\mathrm{M}$ & $\mathrm{L}$ & $\mathrm{M}$ & $\mathrm{H}$ & $\mathrm{L}$ \\
\hline 23 & $\mathrm{M}$ & $\mathrm{L}$ & $\mathrm{L}$ & $\mathrm{L}$ & $\mathrm{L}$ \\
\hline 24 & L & $\mathrm{L}$ & $\mathrm{L}$ & $\mathrm{L}$ & $\mathrm{L}$ \\
\hline 25 & $\mathrm{~L}$ & $\mathrm{~L}$ & $\mathrm{~L}$ & $\mathrm{M}$ & $\mathrm{L}$ \\
\hline 26 & $\mathrm{~L}$ & $\mathrm{~L}$ & $\mathrm{~L}$ & $\mathrm{H}$ & $\mathrm{L}$ \\
\hline 27 & $\mathrm{~L}$ & $\mathrm{M}$ & $\mathrm{M}$ & $\mathrm{H}$ & $\mathrm{L}$ \\
\hline 28 & $\mathrm{~L}$ & $\mathrm{M}$ & $\mathrm{L}$ & $\mathrm{H}$ & $\mathrm{L}$ \\
\hline 29 & $\mathrm{~L}$ & $\mathrm{~L}$ & $\mathrm{M}$ & $\mathrm{H}$ & $\mathrm{L}$ \\
\hline 30 & $\mathrm{~L}$ & $\mathrm{M}$ & $\mathrm{M}$ & $\mathrm{M}$ & $\mathrm{L}$ \\
\hline 31 & $\mathrm{~L}$ & $\mathrm{M}$ & $\mathrm{M}$ & $\mathrm{L}$ & $\mathrm{L}$ \\
\hline 32 & $\mathrm{~L}$ & $\mathrm{H}$ & $\mathrm{H}$ & $\mathrm{H}$ & $\mathrm{L}$ \\
\hline 33 & $\mathrm{~L}$ & $\mathrm{M}$ & $\mathrm{L}$ & $\mathrm{M}$ & $\mathrm{L}$ \\
\hline 34 & $\mathrm{~L}$ & $\mathrm{~L}$ & $\mathrm{M}$ & $\mathrm{M}$ & $\mathrm{L}$ \\
\hline 35 & $\mathrm{~L}$ & $\mathrm{H}$ & $\mathrm{M}$ & $\mathrm{M}$ & $\mathrm{L}$ \\
\hline 36 & $\mathrm{~L}$ & $\mathrm{H}$ & $\mathrm{M}$ & $\mathrm{H}$ & $\mathrm{L}$ \\
\hline 37 & $\mathrm{~L}$ & $\mathrm{H}$ & $\mathrm{H}$ & $\mathrm{M}$ & $\mathrm{L}$ \\
\hline 38 & $\mathrm{~L}$ & $\mathrm{H}$ & $\mathrm{M}$ & $\mathrm{L}$ & $\mathrm{L}$ \\
\hline 39 & $\mathrm{~L}$ & $\mathrm{M}$ & $\mathrm{L}$ & $\mathrm{L}$ & $\mathrm{L}$ \\
\hline 40 & $\mathrm{~L}$ & $\mathrm{M}$ & $\mathrm{H}$ & $\mathrm{M}$ & $\mathrm{L}$ \\
\hline
\end{tabular}

For the proposed hierarchical knowledge base, the maximum number of rules is: $35+36+33+34=1080$ (Shtovba, 2007). However, one important peculiarity of fuzzy knowledge bases has to be taken into account - the search for all possible rules deprives the system of flexibility, the ability to adapt to real conditions. Therefore, the number of rules in each knowledge base should be less than the number of all possible combinations of the values of the input variables. If the knowledge base does not have a rule that corresponds to a particular situation, the system offers the solution that is most suitable for this situation, namely, a solution for which the membership function will have the highest value. In addition, the lack of certain combinations of input variables is explained by economic content. In practice, it does not always have any combination of values of input variables. For example, in Table 4, if "Genetic purity of seeds" is high, then all other factors cannot be low (high or medium only), because genetically pure seeds are an expensive resource and can be used only by the manufacturer who provides the proper level of all other factors. The same explanation can be given in the absence of certain combinations of input variables in all other tables.

Fuzzy logical output of Mammadi is realized by the following operations:

- And method - by operation of the minimum;

- Implication - by operation of the minimum;

- Aggregation - by operation of the maximum;

- Defuzzification - by the method of the centre of gravity (centroid).

In the Fuzzy Logic Toolbox, implementation of logical operations, methods of implication, aggregation, and dephasing is programmed. They can be s set by using the following menu (Fig. 3). 


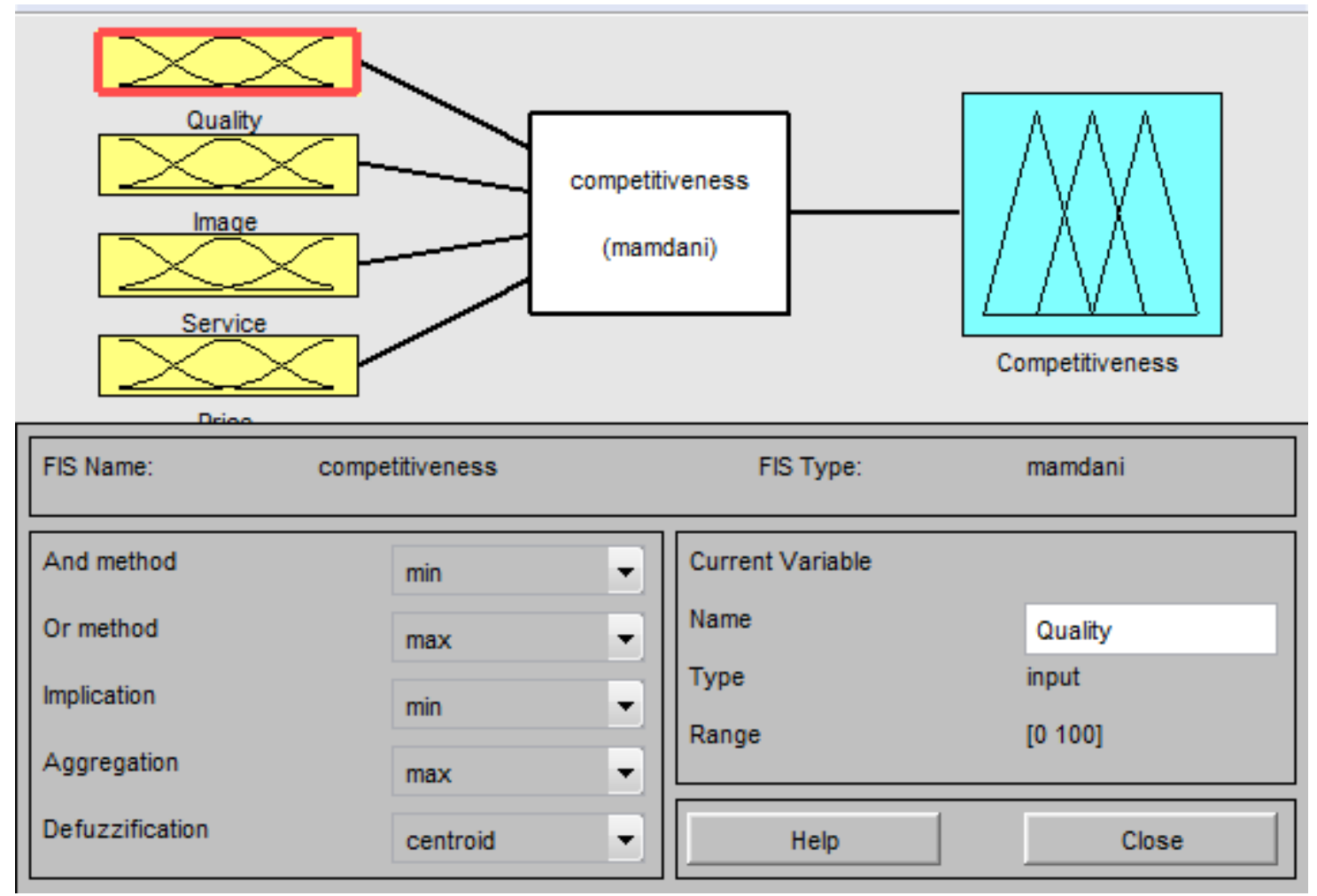

Figure 3: Operations and methods of fuzzy logical inferance of Mamdani. Source: own

\subsubsection{Formation of fuzzy knowledge bases}

To assess the adequacy of the model, we used a training sample containing 120 "input-output" observations, which were generated randomly. Taking into account the results obtained, the knowledge bases were adjusted (Tables 4-7 present its final version). Figure 4 shows a three-dimensional graph presenting the dependence of the level of oil competitiveness on quality and price (level of the image is 75 and level of service is 65 ).

The analysis on the basis of a given graph is approximate. Due to the importance of usage accurate data about the dependence of competitiveness on the level of complex factors (quality, image, service) and price, an analysis of sensitivity was carried out in the work.

\subsection{Simulation of the competitiveness sensitivity of a particular oil brand}

In the next step, three major oil brands were chosen to analyse their competitiveness levels. They were selected on the basis of analysis of official financial statements (SSSU, 2018) and their market share (UCAB, 2018) for the last five years. Due to obtained data, such brands as "Chumak", "Korolivskyj smak", and "Majola" are the most demanded ones (Bakertilly, 2017) and considered as main competitor at domestic market.

The research conducted allowed the researchers to evaluate and compare the level of competitiveness of major Ukrainian sunflower oil trademarks. Using the developed model, the competitiveness levels of three major sunflower oil brands were calculated (Table 8). 
As judged by the data given in Table 3 and Table 8, it is possible to make some conclusions about the level of competitiveness of different brands of sunflower oil and the factors influencing it.

"Chumak" oil is characterised by high quality, and the manufacturer has a fairly strong image. The service lev- el can be referred to as high rather than average, but the price is high. Therefore, the level of competitiveness of this product is approaching the average level.

In the case of "Korolivskyj smak", one can state that the

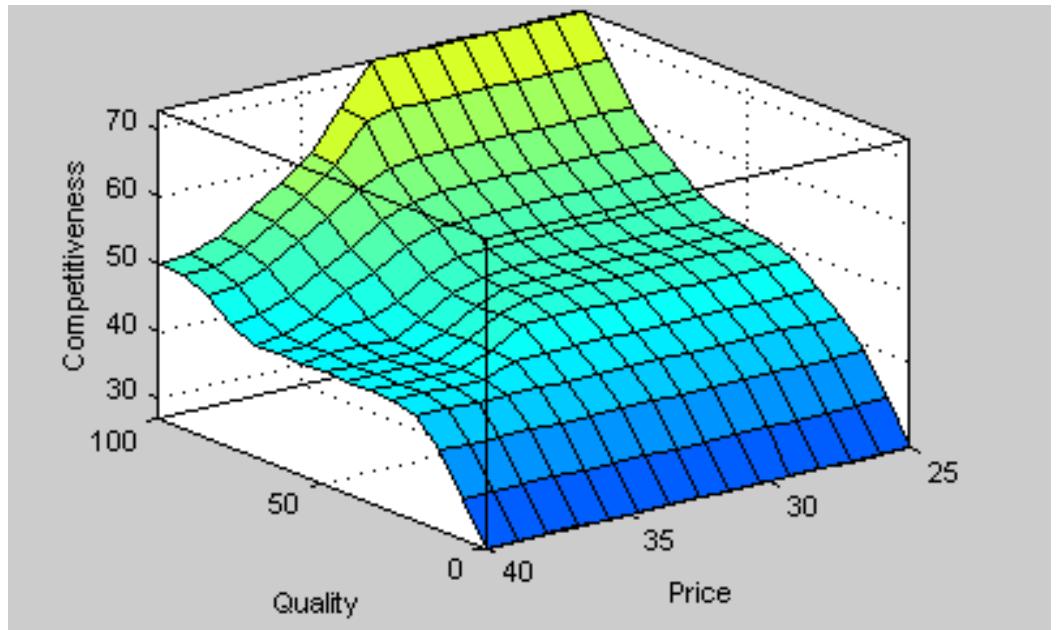

Figure 4. Three-dimensional graph presenting the dependence of the level of oil competitiveness on quality and price (obtained after setting the model on the training sample). Source: own

quality of its sunflower oil and its image is considered high rather than average. In contrast, the service level tends to be above average and the price is clearly average (the coordinate of the maximum of the membership function for the average price is equal to $32,5 \mathrm{UAH}$. Taking into account the points garnered in terms of all aggregated factors, the level of competitiveness of this sunflower oil is equal to 57,8 .

Regarding sunflower oil produced by "Majola", one can declare an average level of quality, manufacturer image, and service. We can say with a greater degree of cer- tainty that the price is definitely average. Thus, as a consequence, Myola's level of sunflower oil competitiveness can be described as average.

A comparison of the estimations obtained allows us to conclude that "Korolivskyj smak" sunflower oil has a high level of competitiveness, characterised by favourable relations of price and non-price factors.

Taking into account the level of all non-price competitiveness factors, it can be noted that the price of "Mayola" oil is quite high in comparison with "Korolivskyj smak" sunflower oil. "Chumak" sunflower oil has a high level of

Table 8: Indicators for assessing the level of competitiveness of different brands of packaged sunflower oil. Source: own

\begin{tabular}{|l|c|c|c|c|c|}
\hline \multicolumn{1}{|c|}{ Trademark Name } & $\begin{array}{c}\text { Quality } \\
\left(\mathrm{F}_{1}\right)\end{array}$ & $\begin{array}{c}\text { Image } \\
\left(\mathrm{F}_{2}\right)\end{array}$ & $\begin{array}{c}\text { Service } \\
\left(\mathrm{F}_{3}\right)\end{array}$ & $\begin{array}{c}\text { Average retail price, } \\
\text { UAH/L } \\
\left(\mathrm{F}_{4}\right)\end{array}$ & $\begin{array}{c}\text { Sunflower oil com- } \\
\text { petitiveness level (C) }\end{array}$ \\
\hline Chumak & 88 & 91 & 76 & 37 & 53.3 \\
\hline Korolivskyj smak & 78 & 76 & 69 & 32 & 57.8 \\
\hline Majola & 53 & 48 & 51 & 29 & 50 \\
\hline
\end{tabular}


non-price factors, but a relatively high price reduces its competitiveness compared to "Korolivskyj smak" oil.

The developed model allows us to carry out an analysis of the sensitivity of the resultant index to the change of values of input variables.

We have analyzed the sensitivity of the level of competitiveness of the "Chumak" sunflower oil to the following factors: price reduction; increase of service level; decrease in oil quality. The level of image remains the same. It was supposed that in case of decreasing oil quality, producer with high image has either inform consumers on a given issue or remove oil from the retail chain. Consequently it could trigger the spread of negative reviews of trademark and in more remote period - reduced producers' image.

The values of the factors we changed as follows: the price was reduced in step size of UAH 0,10 to average price level since it is important for the producer to keep the price at least at the average level $(32,5 \mathrm{UAH}$ is the coordinate of the maximum of the membership function for the average price); service increased in step 1 to the maximum level of 100; the quality was reduced in step 1 to the average level ( 50 is the coordinate of the maximum of the membership function for the average quality).

The next step of our research is to analyse the sensitivity of the level of "Chumak" sunflower oil competitiveness to changes in price and service (Table 9).

According to the results, the following solutions can be proposed for "Chumak":

- decreasing the price by $4,05 \%$ (up to UAH 35,5 per 1 litre) under the condition of invariability of all other factors will allow producers to increase the level of competitiveness of "Chumak" sunflower oil by $8,6 \%$ $(\mathrm{C}=57.9)$. As the result competitiveness of "Chumak" sunflower oil will surpass the competitiveness level of "Korolivskyj smak" sunflower oil $(\mathrm{C}=57.8)$;

- a 31,6\% improvement of the service level (up to the maximum possible value of $F 3=100$ ), provided that all other factors remain unchanged, will increase the level of competitiveness of "Chumak" brand oil by only $0,38 \%$ (up to the level of $\mathrm{C}=53,5$ ), which indicates the inexpediency of placing significant emphasis on service only;

- a $20,45 \%$ decline in oil quality (up to $F 1=70$ ) doesn't provoke a decline in oil competitiveness, which could be explained by the high confidence of buyers in the brand (this is possible only in the short term);

- $\quad$ reducing the quality of oil by $21.59 \%$ (to F1 $=69$ ) already leads to reduction in the competitiveness level by $0,75 \%$ (up to $\mathrm{C}=52.9$ ); further deterioration in quality causes a constant decline in the competitiveness of oil;

- it is rational to reduce the price and improve the service simultaneously. In particular, if price decreases by $3,24 \%$ (up to UAH 35,8 per 1 litre) and service level improves by $15,8 \%$ (up to $\mathrm{F} 3=88$ ) then the level of oil competitiveness will increase by $9 \%$ and will make $\mathrm{C}=58,1$, which will exceed the level of competitiveness of "Korolivskyj smak" sunflower oil $(\mathrm{C}=57,8)$.

Table 9: Results of the sensitivity analysis of the level of competitiveness of "Chumak" packaged sunflower oil to changes in price and service level. Source: own

\begin{tabular}{|c|c|c|c|c|c|c|c|c|c|c|c|c|c|c|c|c|c|}
\hline $\begin{array}{c}\text { Fac- } \\
\text { tors }\end{array}$ & 1 & 2 & 3 & 4 & 5 & 6 & 7 & 8 & 9 & 10 & 11 & 12 & 13 & 14 & 15 & 16 & 17 \\
\hline $\begin{array}{c}\text { Price } \\
\left(\mathrm{F}_{4}\right)\end{array}$ & 37 & 36.9 & 36.8 & 36.7 & 36.6 & 36.5 & 36.4 & 36.3 & 36.2 & 36.1 & 36,0 & 35.9 & 35.8 & 35.7 & 35.6 & 35.5 & 35.4 \\
\hline $\mathrm{C}$ & 53.3 & 53.6 & 53.9 & 54.2 & 54.5 & 54.9 & 55.2 & 55.6 & 56.1 & 56.6 & 56.7 & 56.9 & 57.1 & 57.4 & 57.6 & 57.9 & 58.2 \\
\hline $\begin{array}{c}\text { Price } \\
\left(\mathrm{F}_{4}\right)\end{array}$ & 35.3 & 35.2 & 35.1 & 35.0 & 34.9 & 34.8 & 34.7 & 34.6 & 34.5 & 34.4 & 34.3 & 34.2 & 34.1 & 34.0 & 33.9 & 33.8 & 33.7 \\
\hline $\mathrm{C}$ & 58.5 & 58.8 & 59.1 & 59.5 & 59.9 & 60.3 & 60.7 & 61.1 & 61.6 & 62.0 & 62.5 & 63.0 & 63.5 & 64.0 & 64.5 & 64.9 & 65.0 \\
\hline $\begin{array}{c}\text { Price } \\
\left(\mathrm{F}_{4}\right)\end{array}$ & 33.6 & 33.5 & 33.4 & 33.3 & 33.2 & 33.1 & 33.0 & 32.9 & 32.8 & 32.7 & 32.6 & 32.5 & & & & & \\
\hline $\mathrm{C}$ & 65.2 & 65.3 & 65.5 & 65.6 & 65.7 & 65.7 & 65.8 & 65.8 & 65.9 & 65.9 & 65.9 & 65.9 & & & & & \\
\hline \multicolumn{10}{|c|}{ Dependence of competitiveness level on the service at the current level of all other factors } \\
\hline $\begin{array}{c}\text { Ser- } \\
\text { vice } \\
\left(\mathrm{F}_{3}\right)\end{array}$
\end{tabular}


Table 9: Results of the sensitivity analysis of the level of competitiveness of "Chumak" packaged sunflower oil to changes in price and service level. (continued)

\begin{tabular}{|c|c|c|c|c|c|c|c|c|c|c|c|c|c|c|c|c|c|}
\hline $\mathrm{C}$ & 53.3 & 53.3 & 53.3 & 53.3 & 53.3 & 53.3 & 53.3 & 53.3 & 53.3 & 53.3 & 53.3 & 53.3 & 53.3 & 53.3 & 53.3 & 53.3 & 53.3 \\
\hline $\begin{array}{l}\text { Ser- } \\
\text { vice } \\
\left(\mathrm{F}_{3}\right)\end{array}$ & 93 & 94 & 95 & 96 & 97 & 98 & 99 & 100 & & & & & & & & & \\
\hline $\mathrm{C}$ & 53.3 & 53.3 & 53.4 & 53.4 & 53.4 & 53.5 & 53.5 & 53.5 & & & & & & & & & \\
\hline \multicolumn{18}{|c|}{ Dependence of competitiveness level on the quality at the current level of all other factors } \\
\hline $\begin{array}{c}\text { Qual- } \\
\text { ity } \\
\left(\mathrm{F}_{1}\right)\end{array}$ & 88 & 87 & 86 & 85 & 84 & 83 & 82 & 81 & 80 & 79 & 78 & 77 & 76 & 75 & 74 & 73 & 72 \\
\hline $\mathrm{C}$ & 53.3 & 53.3 & 53.3 & 53.3 & 53.3 & 53.3 & 53.3 & 53.3 & 53.3 & 53.3 & 53.3 & 53.3 & 53.3 & 53.3 & 53.3 & 53.3 & 53.3 \\
\hline $\begin{array}{c}\text { Qual- } \\
\text { ity } \\
\left(\mathrm{F}_{1}\right)\end{array}$ & 71 & 70 & 69 & 68 & 67 & 66 & 65 & 64 & 63 & 62 & 61 & 60 & 59 & 58 & 57 & 56 & 55 \\
\hline $\mathrm{C}$ & 53.3 & 53.3 & 52.9 & 52.5 & 52.1 & 51.7 & 51.4 & 51.1 & 50.8 & 50.6 & 50.4 & 50.2 & 50.0 & 49.9 & 49.7 & 49.6 & 49.6 \\
\hline $\begin{array}{c}\text { Qual- } \\
\text { ity } \\
\left(\mathrm{F}_{1}\right)\end{array}$ & 54 & 53 & 52 & 51 & 50 & & & & & & & & & & & & \\
\hline $\mathrm{C}$ & 49.5 & 49.4 & 49.4 & 49.4 & 49.4 & & & & & & & & & & & & \\
\hline \multicolumn{18}{|c|}{ Changes in the competitiveness level in case of service improvement and price reduction at the existing level of all other factors } \\
\hline $\begin{array}{c}\text { Price } \\
\left(\mathrm{F}_{4}\right)\end{array}$ & 37 & 36.9 & 36.8 & 36.7 & 36.6 & 36.5 & 36.4 & 36.3 & 36.2 & 36.1 & 36,0 & 35.9 & 35.8 & 35.7 & 35.6 & 35.5 & 35.4 \\
\hline $\begin{array}{l}\text { Ser- } \\
\text { vice } \\
\left(\mathrm{F}_{3}\right)\end{array}$ & 76 & 77 & 78 & 79 & 80 & 81 & 82 & 83 & 84 & 85 & 86 & 87 & 88 & 89 & 90 & 91 & 92 \\
\hline $\mathrm{C}$ & 53.3 & 53.5 & 53.7 & 54.0 & 54.4 & 54.8 & 55.2 & 55.6 & 56.1 & 56.8 & 57.1 & 57.6 & 58.1 & 58.7 & 59.3 & 59.8 & 60.6 \\
\hline $\begin{array}{c}\text { Price } \\
\left(\mathrm{F}_{4}\right)\end{array}$ & 35.3 & 35.2 & 35.1 & 35.0 & 34.9 & 34.8 & 34.7 & 34.6 & 34.5 & 34.4 & 34.3 & 34.2 & 34.1 & 34.0 & 33.9 & 33.8 & 33.7 \\
\hline $\begin{array}{l}\text { Ser- } \\
\text { vice } \\
\left(\mathrm{F}_{3}\right)\end{array}$ & 93 & 94 & 95 & 96 & 97 & 98 & 99 & 100 & & & & & & & & & \\
\hline $\mathrm{C}$ & 61.3 & 61.8 & 62.6 & 63.5 & 64.2 & 64.9 & 65.6 & 66.3 & & & & & & & & & \\
\hline
\end{tabular}

This business case may help managers to channel their efforts and resources in the proper particular direction to increase product competitiveness and product positioning on the market.

\section{Conclusions}

The paper has addressed the question of evaluating competitiveness considering determining factors. Based on this, a fuzzy model of brand competitiveness and its practical application for Ukrainian sunflower oil were proposed. The aim of this model was to outline essential qualitative and quantitative competitiveness factors (complex and partial) and to evaluate the level of competitiveness re- garding their significance. The main idea behind using the fuzzy logic toolkit is that all factors determining the level of competitiveness (both quantitative and qualitative) were considered. The implementation of this model allows to estimate the level of complex factors of oil competitiveness, which depend on the values of partial factors, to estimate the level of sunflower oil competitiveness considering the values of complex factors. In addition, another important feature of the model is the possibility for researchers to analyse the sensitivity of oil competitiveness to changes in the values of factors.

Our study contributes to the knowledge base in several ways. Firstly, although this research adopts a single-country approach, it gives us the possibility of comparing the results with other sectors of the economy. Secondly, this 
detailed analysis may become a substantial advantage allowing us to formulate hypotheses to be verified in the context of other industries and countries.

One should also add that the model for the evaluation of the level of competitiveness of sunflower oil developed in this paper has several practical applications. First of all, it allows researchers to forecast the level of oil competitiveness taking into account the values of complex factors and price. In addition, it also allows for the assessment of the level of complex factors, while simultaneously taking into account the values of particular factors. As a result it allows researchers to conduct an analysis of the sensitivity of product competitiveness to the impact of significant factors (partial and complex). The results of such analysis could provide a starting point for decision-making in order to improve product competitiveness. In addition, the model can be used for case studies to predict the competitiveness of other food products produced from agricultural raw materials by adjusting its parameters (linguistic variables and their corresponding term sets, functions of membership of fuzzy terms, and fuzzy knowledge bases).

Our study has several limitations, the first (and most important) of which was the analysis of only one product produced by one country. Despite this limitation, we believe that the results achieved allowed us to obtain a true picture of the situation of the product analysed, thus contributing to academic debates of the comprehensive evaluation of product competitiveness.

\section{Literature}

Baker Tilly Ukraine LLP. (2017, August). Vyrobnytstvo vysokooleinovykh kultur $\mathrm{v}$ Ukraini: perspektyvy ta rozvytok [Production of high-oleic cultures in Ukraine: prospects and development]. Retrieved March 2, 2019, from https://bakertilly.ua/news/id41132

Bhana, N. (2018). Corporate social responsibility initiatives and its impact on firm share price performance: Evidence from South Africa, Journal of Contemporary Management, 15(1), 100-126.

Chang, Y.-H. \& Yeh, Ch.-H. (2001). Evaluating airline competitiveness using multiattribute decision making, 29(5), 405-415, http://doi.org/10.1016/S0305-0483(01)00032-9

Chepurnoj, I.P. (2005). Konkurentosposobnost' prodovol 'stvenny kh tovarov [Competitiveness of Food Products]. Moskva: Dashkov i K.

Cygler, J., Sroka, W., Solesvik, M. \& Dębkowska, K. (2018). Benefits and drawbacks of coopetition: the roles of scope and durability in coopetitive relationships, Sustainability, 10, 2688, http://doi.org/10.3390/su10082688

Cygler, J. \& Sroka, W. (2017). Coopetition disadvantages: The case of the high tech companies, Engineering Economics, 28(5): 494-504, http://doi.org/10.5755/j01.ee.28.5.16421

Duarte, A.M. Jr. (2018). Applying the TODIM Fuzzy Method to the evaluation of Brazilian banks, Pesquisa Operacional, 38(1), 153-171, http://doi.org/10.1590/0101-7438.2018.038.01.0153

Dvorsky, J., Popp, J., Virglerova, Z., Kovács, S. \& Oláh, J. (2018). Assessing the importance of market risk and its sources in the SME of the Visegrad Group and Serbia, Advances in Decision Sciences, 22(A) 22nd Anniversary Special Issue, 1-25.

Fatkhutdinov, R.A. (2000). Konkurentosposobnost': ekonomika, strategiya, upravlenie [Competitiveness: Economy, Strategy, Control]. Moskva: Infra-M.

Fumio, T. (1985). Product competitiveness evaluation quantitative analysis for development strategy, Technological Forecasting and Social Change, 28(2), 123139, http://doi.org/10.1016/0040-1625(85)90010-1

Ivanenko, A.V. (2012). Alhorytm otsinky konkurentospromozhnosti produktsii [Algorithm of an estimation of a production competitiveness]. Visnyk ekonomiky transportu i promyslovosti, 38, 182-185.

Kliestikova, J., Krizanova, A., Corejova, T., Kral, P. \& Spuchlakova, E. (2018). Subsidies to increase remote pollution?, Science and Engineering Ethics, 24(2), 755-767, http://doi.org/10.1007/s11948-017-9908-0

Kobyliatskyi, L.S. (2003). Upravlinnia konkurentospromozhnistiu [Management of competitiveness]. Kyiv: Zovnishnia torhivlia.

Kolářová, I., Bédiová, M. \& Rašticová, M. (2017). Job opportunities for people over 50 in the Netherlands, Forum Scientiae Oeconomia, 5(1), 121-128, http://doi.org/10.23762/fso_vol5no1_10

Kozma, T. (2017). Cooperation in the supply chain network, Forum Scientiae Oeconomia, 5(3), 45-58, http://doi.org/10.23762/FSO_vol5no3 173

Kubíčková L., Hajko, V., Rašticová, M. \& Hazuchová, N. (2018). Active Work Participation of the Czech Elderly. Acta Universitatis Agriculturae et Silviculturae Mendelianae Brunensis, 66(5), 1287 - 1293, http://doi.org/10.11118/actaun201866051287

Litvinova, V.O. (2013). Porivnialnyi analiz rozrakhunkovykh metodiv vyznachennia rivnia konkurentospromozhnosti produktsii [Comparative analysis of computational methods for determining the level of competitiveness of products], Visnyk sotsialno-ekonomichnykh doslidzhen, 4, 81-87.

Mamdani, E.H. \& Assilian, S. (1975). An Experiment in Linguistic Synthesis with Fuzzy Logic Controller. Int. J. Man-Machine Studies, 7(1), 1-13.

Massey, G., Kliestikova, J., Kovacova, M. \& Dengov, V.V. (2018). The perceived accuracy of fake news: Mechanisms facilitating the spread of alternative truths, the crisis of informational objectivity, and the decline of trust in journalistic narratives, Geopolitics, History, and International Relations, 10(2), 37-43, http://doi.org/10.22381/GHIR10220184 
Math Works (2018). Fuzzy Logic Toolbox at MATLAB. Retrieved from

https://www.mathworks.com/products/fuzzy-logic. html (2 March 2019).

Matviichyk, A.V. (2005). Analiz ta prohnozuvannia rozvytku finansovo-ekonomichnykh system iz vykorystanniam teorii nechitkoi lohiky [Analysis and forecasting of the development of financial and economic systems using the theory of fuzzy logic]. Kyiv: Tsentr navchalnoi literatury.

Meyer, N. \& De Jongh, J.J. (2018). The importance of entrepreneurship as a contributing factor to economic growth and development: The case of selected European countries, Journal of Economics and Behavioral Studies, 10(4), 287-299,

http://doi.org10.22610/jebs.v10i4.2428

Meyer, N. \& Meyer, D.F. (2017). An econometric analysis of entrepreneurial activity, economic growth and employment: The case of the BRICS countries, International Journal of Economic Perspectives, 11(2), 429-441.

Meyer, N. (2018). South African female entrepreneurs' intention to remain in business, Vanderbijlpark: NorthWest University (Doctoral thesis).

Miller, G.A. (1956), The magic number seven plus or minus two: some limits on our capacity for processing information, Psychological Review, 63, 81-97.

Mityushkin Yu.I., Mokin, B.I., \& Rotshtejn, A.P. (2002). Soft Computing: identifikacziya zakonomernostej nechetkimi bazami znanij [Soft computing: identification of the regularities by the fuzzy knowledge bases]. Vinnytsia: UNIVERSUM-Vinnytsia.

Mohalajeng, L.E. \& Kroon, J. (2016). Perceptions by users of an Open Innovation platform regarding the innovation value chain, Journal of Contemporary Management, 13(1), 892-925.

Moravcikova, D., Krizanova, A., Kliestikova, J. \& Rypakova, M. (2017). Green marketing as the source of the competitive advantage of the business, Sustainability, 9(12), 2218, http://doi.org/3390/su9122218

Oral, M. \& Kettani, O. (2009). Modelling firm competitiveness for strategy formulation, CIRRELT 2009, 52, 1-39. Retrieved from

https://www.google.com/url?sa=t\&rct=j\&q=\&es$\mathrm{rc}=\mathrm{s} \&$ source $=$ web \& $\mathrm{cd}=1 \& \mathrm{ved}=2 \mathrm{ahUKEwj} 3 \mathrm{x}-$ MXZy7fiAhUKLlAKHZ7IBB8QFjAAegQIAB AC\&url=https $\% 3 \mathrm{~A} \% 2 \mathrm{~F} \% 2 \mathrm{Fwww}$.cirrelt. ca\%2FDocumentsTravail\%2FCIRRELT-2009-52.pdf\&usg=AOvVaw1-Vx50ZB2d89xCRi906I13

Pastushchyn, V. (2007). Analiz metodiv otsinky konkurentospromozhnosti produktsii pidpryiemstva [Analysis of methods for assessing the competitiveness of enterprise products]. Ukrainska nauka: mynule, suchasne, maibutnie, 12, 232-240.

Pedrycz, W. (2011). Fuzzy multicriteria decision-making: Models, methods and applications, Chichester: Wiley.
Pomffyová, M., Kožárová, M., \& Krajčík, V. (2017). Innovative and information perspectives of business management, Polish Journal of Management Studies, 16(2), 221-232, http://doi.org/10.17512/pjms.2017.16.2.19

Popp, J., Oláh, J., Fári, M., Balogh, P. \& Lakner, Z. (2018). The GM - regulation game - The case of Hungary, International Food and Agribusiness Management Review, 21(7), 945-968, http://doi.org/10.22434/IFAMR2017.0065

Popp, J., Kiss, A., Oláh, J., Máté, D., Bai, A. \& Lakner, Z. (2018). Network analysis for the improvement of food safety in the international honey trade, Amfiteatru Economic, 20(47), 84-98, http://doi.org/10.24818/EA/2018/47/84

Roostika, R., Wahyuningsih, T., \& Haryono, S. (2015). The impacts of external competitiveness factors in the handicrafts industry, Polish Journal of Management Studies, 12(1), 166-176.

Shpak, N., Kyrylych, T., \& Greblikaite, J. (2016). Diversification models of sales activity for steady development of an enterprise, Sustainability, 8(4), 393, http://doi.org/10.3390/su8040393

Shtovba, S.D. (2007). Proektirovanie nechetkikh sistem sredstvami MATLAB [Design of fuzzy systems by means of MATLAB]. Moskva: Goryachaya liniya Telekom

Shtovba, S. \& Shtovba, O. (2006). Prediction of competitive position of brand product by fuzzy knowledge base. Journal of Automation and Information Sciences, 38(8), 69-80, http://doi.org/10.1615/J Automat Inf Scien.v38.i8.70

Sroka, W. \& Vveinhardt, J. (2018). Nepotism and favouritism in the steel industry: A case study analysis, Forum Scientiae Oeconomia 6(1), 31-45, http://doi.org/10.23762/FSO_VOL6NO1_18 4

State Committee of Ukraine on technical regulation and consumer policy (2006). National Standards of Ukraine 4694-2006 "Sunflower. Olive raw materials. Technological conditions". Retrieved from http://ua-info.biz/ legal/basedt/ua-qmppbr.htm (2 March 2019).

State Statistics Service of Ukraine (SSSU) (2018). Foreign trade in selected products by country Retrieved from http://www.ukrstat.gov.ua/operativ/operativ2018/ zd/e_iovt/arh_iovt2018.htm. (2 March 2019).

Šebestová, J., Šperka, R., Małecka, J. \& Łuczka, T. (2017). Co-working centres as a supportive network for cross border business cooperation, Forum Scientiae Oeconomia, 5(4), 23-34, http://doi.org/10.23762/FSO_ VOL-5NO4_17_2

UCAB (2018). Main indicators of foreign trade of Ukraine. Statistics Service of Ukraine. Retrieved from http://ucab.ua/ua/doing agribusiness/zovnishni rinki/ osnovni pokazniki_zovnishnoi torgivli_ukraini (2 March 2019).

Walsh, V., Roy, R., Bruce, M. \& Potter, S. (1992). Winning by design: technology, product design and internation- 
al competitiveness, Oxford, UK: Blackwell Publishers. Xianbo, Z., Bon-Gang, H. \& Pheng, L.S. (2012). Implementing enterprise risk management in a Chinese construction firm based in Singapore, Proceedings from the World Construction Conference 2012 - Global Challenges in Construction Industry (pp. 434-444), 28-30 June 2012, Colombo, Sri Lanka.

Zhao, X., Hwang, B.-G., Low, S.P. (2013). Developing fuzzy enterprise risk management maturity model for construction firms, Journal of Construction Engineering and Management, 139(9), 1179-1189, http://doi.org/1061/(ASCE)CO.1943-7862.0000712

Nestor Shpak, Dr.Sc., is a professor at the Management and International Business Department, Educational and Scientific Institute of Economics and Management, Lviv Polytechnic National University. Scientific activities: 10 scientific monographs, professional publications, 6 books, more than 200 national and international contributions, and presentations. Research interests: management of innovations, management of infocommunications, modeling of innovative economic systems, marketing activity.

Viktoriya Kharchuk, Ph.D., is an assoc. professor at the Management and International Business Department, Educational and Scientific Institute of Economics and Management, Lviv Polytechnic National University. Scientific activities: 2 scientific monographs, professional publications, 4 books, more than 40 national and international contributions, and presentations. Research interests: financial management, risk management, sustainable development, corporate social responsibility.

Nadiya Seliuchenko, Ph.D., is an assoc. professor at the Department of Business Economics and Investment, Educational and Scientific Institute of Economics and Management, Lviv Polytechnic National University. Scientific activities: scientific monograph, professional publications, 7 books. Research interests: financial management, risk management.

Nataliya Kosar, Ph.D., is an assoc. professor at the Department of Marketing and Logistics, Educational and Scientific Institute of Economics and Management, Lviv Polytechnic National University. Scientific activities: 7 scientific monographs, professionalpublications, 3 books. Research interests: marketingmanagement, marketingresearches, strategic marketing, consumer policy.
Włodzimierz Sroka, Ph.D., is an associate professor in the Management Department of WSB University in Dąbrowa Górnicza. He specializes in theoretical and practical issues relating to management and strategic management. He is the author of numerous scientific papers about strategic alliances, network organizations, strategy, company restructuring, CSR and business ethics, as well as innovations and entrepreneurship. His research activities mostly include cooperative strategies (e.g., alliances, network organizations), coopetitive relations, M\&A, business ethics and CSR, innovations and entrepreneurship. He merges his scientific activity with being the CEO of a medium-sized engineering company. He was previously employed in different managerial positions in both the steel and machine industries. 